Dragutin Babić

\section{Nacionalne manjine u Hrvatskoj: sociološka perspektiva}

Zagreb: Plejada, 2015, 280 str.

DOI: $10.11567 / m e t .32 .1 .7$

Nakon raspada jugoslavenske države i završetka ratnih sukoba nacionalne su manjine u hrvatskom društvu doživjele velike normativne, statusne i egzistencijalne promjene. Iako se to ne odnosi podjednako na sve manjine, njihov ih manjinski status neosporno svrstava $\mathrm{u}$ društvenu skupinu koja je drugačija od etničke većine. Primjenom kvantitativne i kvalitativne metodologije autor nas $u$ šest poglavlja knjige upoznaje s trenutačnim stanjem nacionalnih manjina $u$ Republici Hrvatskoj (posebice najbrojnije srpske). Uz prikaz rezultata iznosi i vlastite interpretacije koje su u skladu s razrađenim teorijskim okvirom iz kojeg se vidi njegovo poznavanje problematike i iščitava veliki trud u promišljanju tema koje se tiču nacionalnih manjina.

U uvodu »Postajanje manjinom svi smo mi manjinci? « se autor pita tko čini manjinu u društvu, jesmo li svi mi zapravo pripadnici neke od manjina te kako izgleda i o čemu ovisi rangiranje raznolikih (vjerskih, nacionalnih i ostalih) čovjekovih subidentiteta. Može li se, zbog strukturnih poteškoća, pojedinac kvalitetno uključiti u mrežu raznolikih uloga koje mu se nude u svakodnevici? Ako ne može, nameće se zaključak da smo svi mi manjinci. No ako se čvrsto opredijelimo za samo jedan značajni, presudni i usto isključivi identitet $\mathrm{i}$ ako to identitetsko obilježje u kodiranome društveno prostornom kontekstu ima obi- lježje većinskog pripadanja, tada nismo manjinci.

U drugom poglavlju autor se bavi razradom teorijskog okvira. Iznosi brojne definicije nacionalnih manjina različitih autora te sumira njihove ključne elemente - brojnost skupine u odnosu prema drugim takvim skupinama, pitanje (ne)moći u međuodnosu tih skupina, unutarnju koheziju, organiziranost skupine te njezinu kolektivno-simboličku osviještenost. Zatim se dotiče etnonacionalizma ističući kako je on svojevrsna zamjena za klasnu paradigmu socijalističkog poretka. To je rezultiralo posebno poremećenim hrvatsko-srpskim odnosima, što dugoročno opterećuje društvenopolitičku scenu u Republici Hrvatskoj, ali i šire. Nakon toga razmatra pojmove predrasuda, stereotipa i stigmi ističući kako politički i ratni sukobi djeluju kao moćan generator takvih sociopsiholoških obrazaca, što pridonosi isključivanju pripadnika drugih etničkih skupina iz društva (u hrvatskom kontekstu Srba, Albanaca i Roma).

$\mathrm{Na}$ početku trećeg poglavlja »Nacionalna struktura stanovništva hrvatskih županija 1991. -2001. - 2011. « ističe kako su u Republici Hrvatskoj priznate 22 nacionalne manjine, što dokazuje da je Hrvatska i u aktualnom vremenu izrazito multietnički geopolitički prostor. Zatim u obliku deskriptivne statistike iznosi pregled nacionalnih manjina (i većinskih Hrvata) po županijama kroz tri popisa stanovništva (1991., 2001. i 2011.) uvažavajući njihove povijesne, socijalne, političke i ekonomske specifičnosti. Iz prikazanih podataka vidljivo je da županije sjeverozapadne Hrvatske karakterizira duga tradicija etničke homogeno- 
sti - više od 95\% čine Hrvati, izuzev Međimurske, gdje uz 90\% Hrvata nalazimo 4,4\% Roma. Ostale su županije uslijed izloženosti nedavnim ratnim sukobima doživjele značajne promjene etničkog sastava u smjeru povećanja udjela Hrvata i smanjenja udjela Srba (u pojedinim županijama i do tri puta). Iznimka je područje istočne Slavonije, koje je reintegrirano u sastav Republike Hrvatske mirnim putem. Istaknimo još kako se, uz spomenutu srpsku, u Bjelovarsko-bilogorskoj županiji ističe češka, u Osječko-baranjskoj mađarska, a u Istarskoj talijanska nacionalna manjina te da ih, kao »stare« nacionalne manjine, karakterizira visok stupanj organiziranosti i ostvarenih prava. Usporedbom različitih regija, odnosno teritorijalno-političkih jedinica, može se ustvrditi da su etničke promjene različito zahvatile analizirane podcjeline hrvatskog društva/ države. Najveća se uočena razlika odnosi na podjelu ratne zone/područja bez ratnih sukoba. Iako je etnička struktura najviše narušena $u$ odnosu Hrvata i Srba, većina ostalih nacionalnih i etničkih manjina također je doživjela smanjenje u broju i udjelu u stanovništvu hrvatskih županija.

Prvi dio četvrtog poglavlja »Empirijsko istraživanje odnosi se na rezultate ankete provedene među pripadnicima češke, mađarske, slovačke i srpske nacionalne manjine. Ukratko ćemo navesti i prokomentirati neka odabrana pitanja kojih se autor dotaknuo. Ocjene manjina kad je riječ o prijeratnom suživotu kreću se u rasponu od vrlo afirmativnih do onih koji u središte opservacije tih veza stavljaju konflikte i animozitete. Najviše afirmativnih ocjena prijeratne multietničke koegzistencije nalazimo kod Srba s bivših ratnih prostora. Ratni sukobi u bivšoj Jugoslaviji, borba za suverenitet i izrazita etnifikacija svih sfera društva destruirali su u značajnom opsegu mrežnu strukturu primarnih društvenih veza. Rezultati istraživanja pokazuju da većina ispitanika i nakon traumatičnih ratnih zbivanja još uvijek ima prijatelje različitih nacionalnosti. Takvi odgovori pokazuju snagu primarnih društvenih veza te njihovu utemeljenost u kolektivnom imaginariju ispitanika i njihovim funkcionalnim obrascima ponašanja i sudjelovanja u lokalnim zajednicama nakon rata. Nadalje, problematizirana je percepcija mladih o nacionalnom identitetu i eventualnoj ugroženosti nacionalnomanjinskih identiteta $\mathrm{u}$ vrijeme opadajućega, ali još uvijek dovoljno snažnoga hrvatskog etnonacionalizma. Više od polovine ispitanika smatra da su njihov jezik, kultura i običaji donekle ili jako ugroženi. Od nacionalnomanjinskih pripadnika Srbi se osjećaju najugroženijima. Rezultati također pokazuju kako su Srbi najmanje zadovoljni ostvarenjem vlastitih nacionalnomanjinskih prava, posebice oni s bivših ratnih prostora. Kao glavni razlog nezadovoljstva istaknuli su nebrigu države. Drugi dio poglavlja obuhvaća intervjue s pripadnicima njemačke, ukrajinske i romske nacionalne manjine. Najveći je izazov za te manjine bio Drugi svjetski rat, koji ih je podijelio - bilo je onih koji su bili u službi Trećeg Reicha, ali i onih koji su mu se suprotstavili. Upravo na tom primjeru autor pokazuje koliko je inauguracija kolektivne krivnje promašaj sa stajališta analize, ali i konkretna šteta za pojedince (pripadnike optuženih kolektiviteta). Ukrajinci u Hrvatskoj, kao i ostale »stare« nacional- 
ne manjine, doživljavaju kontinuiranu postupnu asimilaciju. U sferi identiteta referiraju se na komunikacijsko sjećanje prenošeno generacijama od dolaska njihovih predaka u Slavoniju. Kazivači ističu da su kao manjina relativno dobro organizirani te izdvajaju pohađanje ljetnih škola, učenje jezika i posjete Ukrajini. Naposljetku, Romi su manjina koji se od ostalih razlikuju prije svega u načinu života te oblikovanju svakodnevne egzistencije, koja je subkulturna u odnosu na društvenu većinu. Romski kazivači podijeljeni su u pogledu iskustava - dok su jedni doživjeli napade, drugi nisu. No i oni koji jesu slažu se da je toga danas manje nego netom nakon rata. Danas ih više muče egzistencijalna pitanja, ponajviše teška pozicija na tržištu rada.

U prvom dijelu petog poglavlja »Sociolog promatrač« autor iznosi stavove nekolicine srednjoškolaca $\mathrm{u} \mathrm{Vu}$ kovaru (Hrvata i Srba) o (odvojenom) školstvu i ćiriličnom pismu u tom gradu. Svi kazivači (i Hrvati i Srbi) smatraju kako još nije došlo vrijeme da zajedno pohađaju nastavu. Napominju kako su tenzije još uvijek prevelike, što često rezultira provokacijama i nesnošljivošću. Ćirilično pismo u posljednje je vrijeme u Vukovaru razdjelnica izmedu »Nas« $\mathrm{i} » N j i h$ « bez obzira na to što je ćirilica također i staro hrvatsko pismo. No ona je simbol koji je važan aspekt identiteta (u slučaju $\mathrm{Vu}$ kovara prije svega srpskoga). U drugom se dijelu autor dotiče participacije Roma u školskom sustavu Međi- murske županije pozivajući se na podatke iz Vladinih izvješća o uključenosti Roma u obrazovni sustav na svim razinama. Iz tih je podataka evidentno kako je njihov broj u blagom porastu, ali da je naglasak ponajprije na osnovnoškolskom obrazovanju. Zaključuje kako će biti potrebno još mnogo javnih akcija i političke podrške toj etničkoj skupini da bi njezina integracija dobila na težini.

U zadnjem poglavlju »Perspektive: nacionalne/etničke manjine $\mathrm{u} \mathrm{Hr}-$ vatskoj - između asimilacije, akulturacije, stigmatizacije, etnomimikrije, segregacije i integracije« autor ističe kako je za demokratsko društvo najpoželjniji proces u međuodnosu nacionalne većine i nacionalnih manjina integracija svih nacionalnih/etničkih zajednica u društvo i državu kao njegov politički okvir. Zaključuje kako će tek dosljedno provođenje demokratskih normi, usvajanje vrijednosti tolerancije, priznanje različitosti i afirmacija politike multikulturalizma omogućiti stvaranje povoljnih pretpostavki za daljnje napredovanje procesa integracije te očuvanje identiteta nacionalnih/etničkih manjina u Hrvatskoj.

Knjiga Dragutina Babića svojim obuhvatom, sistematizacijom pojmova i teorija, sintezom kvantitativne $i$ kvalitativne metodologije te primjenom interpretativnih sadržaja važan je doprinos u razumijevanju položaja, odnosa te procesa koji se tiču nacionalnih manjina, ali i Hrvata na prostoru Republike Hrvatske.

Filip Trbojević 